\title{
ANALISIS PENGARUH KEPEMIMPINAN, MOTIVASI DAN DISIPLIN KERJA TERHADAP KINERJA KARYAWAN TOKO RAYSA PEMADAM JOGLO
}

\section{Ade Setiawan}

Fakultas Ekonomi dan Bisnis, Universitas Budi Luhur, Jakarta, Indonesia

Email: adesetiawan2407@gmail.com

\begin{tabular}{l}
\hline INFO ARTIKEL \\
\hline Diterima \\
28 November 2021 \\
Direvisi \\
15 Desember 2021 \\
Disetujui \\
1 Januari 2022 \\
\hline Kat
\end{tabular}

\section{Kata Kunci:}

Kepemimpinan; Motivasi; Disiplin Kerja; Kinerja Pegawai

\begin{abstract}
ABSTRAK
Kendala yang sering terjadi adalah ketika jadwal pengiriman mengalami keterlambatan, dalam keadaan inilah perlu disiplin kerja yang baik, agar bisa di tindak lanjuti sesegera mungkin sehingga tidak menimbulkan kekecewaan dari konsumen. Penelitian ini bertujuan untuk mendeskripsikan masalah yang ada pada Toko Raysa Pemadam yang dimana perkembangan sektor bisnis kebutuhan dasar rumah tangga (sembako) peluang bagi perusahaan kecil untuk sub pekerjaan sektoral. Memanfaatkan peluang dalam meraih konsumen, menciptakan persaingan antara perusahaan-perusahaan jasa perbaikan serupa. Hal ini juga membuat setiap perusahaan harus menginovasi strategi pemasaran yang kreatif dalam menjual barang yang ditawarkan kepada target sasaran. Penelitian ini bertujuan untuk mengetahui pengaruh kepemimpinan, motivasi dan disiplin kerja terhadap kinerja karyawan, untuk kepemimpinan secara parsial kinerja karyawan. Jenis penelitian yang digunakan dalam penulisan ini merupakan penelitian deskriptif, dengan menggunakan pendekatan kualitatif. Hasil yang diperoleh yakni Toko Raysa Pemadam Joglo merupakan Usaha kecil dibidang kehutuhan rumah tangga (Sembako) di Joglo Jakarta Barat. Hasil yang diperoleh ialah Usaha kecil dan menengah ini (UMKM) melaksanakan kepemimpinan yang baik dengan karyawan, motivasi karyawan dengan bentuk reward kepada karyawannya dan juga tingkat displin yang baik yang mana sangat minim complain dari para konsumen.
\end{abstract}

\section{ABSTRACT}

The obstacle that often occurs is when the delivery schedule is delayed, in this situation good work discipline is needed, so that it can be followed up as soon as possible so as not to cause disappointment from consumers. This study aims to describe the problems that exist in the Raysa Pemadam Store where the development of the basic household needs business sector (sembako) is an opportunity for small companies for sub-sectoral work. Take advantage of opportunities to reach consumers, create competition between similar repair service companies. This also makes every company must innovate creative marketing strategies in selling the goods offered to the target audience. This study aims to determine the effect of leadership, motivation and work discipline on employee performance, for leadership partially employee performance. The type of research used in this paper is descriptive research, using a qualitative approach. The results obtained are that Raysa Pemadam Joglo Shop is a small business in the field of household needs (Sembako) in Joglo, West Jakarta. The

Leadership;

Setiawan, A. (2022). Analisis Pengaruh Kepemimpinan, Motivasi dan Disiplin Kerja Terhadap Kinerja Karyawan Toko Raysa Pemadam Joglo, Jurnal Syntax Transformation, 3(1).

https://doi.org/10.46799/jst.v3i1.487

E-ISSN: $\quad$ 2721-2769

Published by: $\quad$ Ridwan Institute 


\begin{tabular}{ll}
\hline Motivation; Work & results obtained are that these small and medium enterprises (MSMEs) \\
Discipline; & carry out good leadership with employees, motivate employees in the \\
Employee & form of rewards to their employees and also have a good level of \\
Performance & discipline where there are very few complaints from consumers. \\
\hline
\end{tabular}

\section{Pendahuluan}

Sumber Daya Manusia (SDM) sangat penting bagi organisasi/perusahaan dalam mengatur, mengelola, dan memanfaatkan pegawai sehingga dapat berfungsi secara produktif dalam rangka untuk tercapainya tujuan organisasi. Sumber daya manusia suatu perusahaan perlu dikelola secara benar agar tercipta antara kebutuhan pegawai dengan tuntutan dan kemampuan perusahaan tersebut. Berkembangnya suatu perusahaan sangatlah bergantung pada kualitas kinerja dari tenaga kerja yang ada di perusahaan itu sendiri.

Kepemimpinan efektif memiliki peranan penting dan strategis untuk menentukan efektifitas dan efisiensi pencapaian tujuan kelompok dan organisasional (Luthans, 2006).

Motivasi sebagai pendorong atau penggerak perilaku ke arah pencapaian tujuan merupakan suatu siklus yang terdiri dari tiga elemen, yaitu adanya kebutuhan (needs), dorongan untuk berbuat dan bertindak (drives), dan tujuan yang diinginkan (goals). Dorongan tersebut memiliki komponen berupa arah perilaku dan kekuatan perilaku (Muhandri \& Kadarisman, 2012).

Disiplin kerja memberikan manfaat yang positif bagi organisasi, karena dengan adanya disiplin kerja dari dalam diri karyawan dapat menyelesaikan tugas sesuai dengan aturan standar kerja dan tepat waktu sesuai yang telah ditentukan. Menurut (Wirawan, 2009) menjelaskan mengenai disiplin yaitu sikap dan perilaku kepatuhan terhadap peraturan organisasi, prosedur kerja, kode etik, dan norma budaya organisasi lainnya yang harus dipatuhi.

Kepemimpinan, Motivasi dan Disiplin kerja dibutuhkan sekali oleh para karyawan Toko Raysa Pemadam mengingat pekerjaan antara satu bidang pekerjaan dengan bidang pekerjaan lainnya saling berkaitan sehingga jika ada salah satu bidang kerja yang mengalami kesalahan dalam bekerja maka semua pekerjaan akan menjadi terhambat.

Kendala yang sering terjadi adalah ketika jadwal pengiriman mengalami keterlambatan, dalam keadaan inilah perlu disiplin kerja yang baik, agar bisa di tindak lanjuti sesegera mungkin sehingga tidak menimbulkan kekecewaan dari konsumen. Berdasarkan uraian diatas, maka penulis tertarik untuk mengadakan penelitian yang kemudian akan dituangkan dalam bentuk tulisan ilmiah yang berjudul "Analisis Pengaruh Kepemimpinan, Motivasi Dan Disiplin Kerja Terhadap Kinerja Karyawan Toko Raysa Pemadam Joglo.

Penelitian sebelummya yang dilakukan oleh (Sari, 2014) memperoleh hasil bahwa penelitian membuktikan aspek Kepemipinan, motivasi kerja dan aspek disiplin mempunyai pengaruh yang signifikan terhadap kinerja karyawan PT. Patra Komala. Tentunya memiliki perbedaan tempat penelitian akan mempengaruhi hasil penelitian meskipun memili kesamaan indicator objek penelitian yakni kepeminpinan, motivasi kerja dan disiplin.

\section{Metode Penelitian}

Jenis penelitian yang digunakan dalam penulisan ini merupakan penelitian deskriptif, dengan menggunakan pendekatan kualitatif. Penelitian deskriptif adalah suatu bentuk penelitian yang ditujukan untuk mendeskripsikan fenomena-fenomena yang ada, baik fenomena alamiah maupun fenomena buatan manusia. Fenomena itu bisa berupa bentuk, aktivitas, karakteristik, perubahan, hubungan, kesamaan, dan 
perbedaan antara fenomena yang satu dengan fenomena lainnya (Sukmadinata, 2006).

Teknik pengumpulan observasi yang digunakan adalah participant observation, yaitu dimana peneliti terlibat secara langsung dalam kegiatan sehari-hari pada Toko Raysa Pemadam Joglo sebagai sumber data. Teknik pengumpulan dengan cara wawancara yang digunakan adalah wawancara tidak terstruktur, yaitu peneliti hanya memuat poinpoin penting pada kasus Toko Raysa Pemadam Joglo dari responden. Setelah data diperoleh kemudian dilakukan analisis terhadap data yang didapat dari penelitian selanjutnya di reduksi menjadi hasil penelitain dan dibuat kesimpulan.

\section{Hasil dan Pembahasan}

1. Penerapan Kepemimpinan Dalam Meningkatkan Kinerja kepemimpinan di dalam Toko Raysa Pemadam Joglo yang efektif tidak dapat tercapai tanpa inklusi penuh, inisiatif dan kerja sama karyawan. Oleh karenanya pemberian arahan telah dilakukan agar karyawan bekerja sesuai dengan SOP. Penelitian ini sejalan dengan penelitian yang tulis oleh (Ekhsan, 2019) dengan hasil Motivasi dan Disiplin Kerja berpengaruh secara bersama-sama terhadap Kinerja Karyawan pada

PT. Syncrum Logistics. Hal ini menunjukan bahwa secara simultan motivasi kerja dan disiplin

kerja berpengaruh signifikan terhadap kinerja karyawan. Sehingga semakin tinggi motivasi dan semakin kondusif disiplin kerja terhadap karyawan maka semakin tinggi kinerja karyawan.

2. Penerapan Motivasi Dalam Meningkatkan Kinerja

Motivasi sebagai pendorong atau pengerak perilaku ke arah pencapaian tujuan merupakan suatu siklus yang terdiri dari tiga elemen, yaitu adanya kebutuhan (needs), dorongan untuk berbuat dan bertindak (drives), dan tujuan yang diinginkan (goals). Dorongan tersebut memiliki komponen berupa arah perilaku dan kekuatan perilaku. Searah dengan (Mulyono, 2021) bahwasanya Bahwa untuk meningkatkan kinerja publikasi dosen di Jurnal Internasional Terindeks Scopus variabel need for achievement, need for affiliation, need for powertidak bisa berpengaruh secara langsung

3. Penerapan Disiplin Kerja Dalam Meningkatkan Kinerja Karyawan Toko Raysa Pemadam Joglo

Selama ini semua karyawan Toko Raysa Pemadam Joglo sudah bekerja dengan disiplin yaitu sesuai aturan yang berlaku. Selain disiplin waktu dalam bekerja karyawan juga dituntut disiplin dalam bekerja hal ini dilakukan agar meminimalisir keluhan pelanggan (Sutanto \& Suwondo, 2015). Agar kesalahan sekecil apapun bisa terhindar, Toko Raysa Pemadam Joglo akan memberikan sanksi yang tegas terhadap pelanggaran disiplin yang dilakukan karyawan, hal ini dilakukan untuk meminimalisir kerugian usaha serta kepuasan konsumen. Hasil penelitian sebelumnya oleh (PALANGKA, 2021) bahwa penerapan disiplin kerja oleh Honda Delima Motor Sutoyo dalam upaya meningkatkan kinerja karyawan, yaitu memberikan hukuman dan reward kepada karyawan yang berkinerja baik.

4. Penerapan kepemimpinan Motivasi dan Disiplin Kerja Dalam Meningkatkan Kinerja Karyawan Toko Raysa Pemadam Joglo Seharusnya

Kepemimpinan menunjukkan suatu hubungan pengaruh antara pemimpin dan pengikut untuk mencapai tujuan bersama dalam situasi tertentu (Silalahi, 2011). 
Motivasi adalah serangkaian sikap dan nilai - nilai yang mempengaruhi individu untuk mencapai hal yang spesifik sesuai dengan tujuan individu. Sikap dan nilai tersebut merupakan suatu yang invisible yang memberikan kekuasan untuk mendorong individu untuk bertingkah laku dalam pencapaian tujuan (Rivai \& Sagala, 2011).

Disiplin kerja merupakan tindakan manajemen mendorong pegawai memenuhi tuntutan berbagai ketentuan tersebut. Pendisiplinan pegawai adalah suatu bentuk pelatihan yang berusaha memperbaiki dan membentuk pengetahuan, sikap dan perilaku pegawai sehingga para pegawai tersebut secara sukarela berusaha berkerja secara kooperatif dengan para pegawai yang lain serta meningkatkan prestasi kerjanya (Rumondor et al., 2016).

Kepemipinan yang baik (Yudiningsih et al., 2016) memberikan pengaruh postif akan kinerja karyawan agar tercipta nya tujuan bersama (Ghoniyah, 2011). Selain itu motivasi perusahaan berupa reward atau punishment untuk memacu kinerja karyawan agar menghasilkan suatu produk atau jasa yang baik untuk konsumen

Berdasarkan pemaparan disiplin kerja memberikan manfaat yang positif bagi organisasi, karena dengan adanya disiplin kerja dari dalam diri karyawan dapat menyelesaikan tugas sesuai dengan aturan standar kerja dan tepat waktu sesuai yang telah ditentukan. Dengan demikian dapat membantu meningkatkan kinerja karyawan. Disiplin kerja yang dapat direalisasikan dengan baik akan dapat mengurangi karyawan dalam melakukan tindakan yang menyimpang (Oxtaviani, 2021).

\section{Kesimpulan}

Toko Raysa Pemadam Joglo merupakan Usaha kecil dibidang kehutuhan rumah tangga (Sembako) di Joglo Jakarta Barat. Usaha kecil dan menengah ini (UMKM) ini melaksanakan kepemimpinan yang baik dengan karyawan, Motivasi karyawan dengan bentuk reward kepada karyawannya. Dan juga tingkat displin yang baik yang mana sangat minim complain dari para konsumen.

\section{BIBLIOGRAFI}

Ekhsan, M. (2019). Pengaruh Motivasi dan Disiplin Kerja terhadap Kinerja Karyawan. Optimal: Jurnal Ekonomi Dan Kewirausahaan, 13(1), 113.Google Scholar

Ghoniyah, N. (2011). Peningkatan Kinerja Karyawan melalui Kepemimpinan, Lingkungan Kerja dan Komitmen. JDM (Jurnal Dinamika Manajemen), 2(2). Google Scholar

Luthans, F. (2006). Organizational Behavior (terjemahan). Yogyakarta: Andi, 637. Google Scholar

Muhandri, T., \& Kadarisman, D. (2012). Sistem Jaminan Mutu Industri Pangan. PT Penerbit IPB Press. Google Scholar

Mulyono, K. B. (2021). Motivasi Dosen Ekonomi Dalam Meningkatkan Kinerja Publikasi Penelitian: Investigasi Penerapan Nach Theory. Jurnal Pendidikan Ilmu Sosial, 31(1), 43-52. Google Scholar

Oxtaviani, M. (2021). Analisis Pentingnya Disiplin Kerja Dalam Meningkatkan Kinerja Karyawan Pada PT. Delta Prima Steel Jorong. Universitas Islam Kalimantan MAB. Google Scholar

Palangka, Y. (2021). Kebijaksanaan Penerapan Disiplin Kerja Dalam Meningkatkan Kinerja Karyawan Pada Honda Delima Motor Sutoyo. 
Analisis Pengaruh Kepemimpinan, Motivasi dan Disiplin Kerja Terhadap Kinerja Karyawan Toko Raysa Pemadam Joglo

Universitas Islam Kalimantan MAB. Google Scholar

Rivai, V., \& Sagala, E. J. (2011). Edisi Kedua Manajemen Sumber daya Manusia untuk Perusahaan: Dari Teori ke Praktik, Cetakan Keempat. Jakarta: PT RajaGrafindo Persada. Google Scholar

Rumondor, R. B., Tumbel, A., \& Sepang, J. L. (2016). Pengaruh Kepemimpinan, Motivasi, dan Disiplin Kerja terhadap Kinerja Pegawai pada Kanwil Ditjen Kekayaan Negara Suluttenggomalut. Jurnal EMBA: Jurnal Riset Ekonomi, Manajemen, Bisnis Dan Akuntansi, 4(2). Google Scholar

Sari, Y. K. (2014). Pengaruh kepemimpinan, motivasi dan disiplin kerja terhadap kinerja karyawan pada PT. Patra Komala di Dumai. Jurnal Tepak Manajemen Bisnis, 6(2), 119-127. Google Scholar

Silalahi, U. (2011). Kepercayaan Publik kepada Pemerintah Daerah Pasca Orde Baru. JIANA (Jurnal Ilmu Administrasi Negara), 11(02). Google Scholar

Sukmadinata. (2006). Metode Penelitian Kualitatif. Graha Aksara. Google Scholar

Sutanto, E. M., \& Suwondo, D. I. (2015). Hubungan lingkungan kerja, disiplin kerja, dan kinerja karyawan. Jurnal Manajemen Dan Kewirausahaan, 17(2), 135-144. Google Scholar

Wirawan. (2009). Evaluasi Kinerja Sumber Daya Manusia: teori, aplikasi, dan penelitian. Salemba Empat. Google Scholar

Yudiningsih, N. M. D., Yudiaatmaja, F., Yulianthini, N. N., \& SE, M. M. (2016). Pengaruh Lingkungan Kerja Dan Disiplin Kerja Terhadap Kinerja Pegawai. Jurnal Manajemen Indonesia, 4(1). Google Scholar

\section{Copyright holder :}

Ade Setiawan (2022)

First publication right :

Jurnal Syntax Transformation

This article is licensed under: 